\title{
Etnomathematic Analysis: Implementation of the Ecentric Digraph in Determining the Ka'ba as Center of the Earth
}

\author{
Marwah Daud Wijayanti ${ }^{1)}$, Detalia Noriza Munahefi ${ }^{2)}$, \\ Kristina Wijayanti ${ }^{3)}$, Agung Prabowo4, ${ }^{*}$ \\ ${ }^{1,4)}$ Department of Mathematics, Faculty of Mathematics and Natural Sciences \\ Universitas Jenderal Soedirman \\ ${ }^{2.3)}$ Department of Mathematics, Faculty of Mathematics and Natural Sciences \\ Universitas Negeri Semarang \\ *Corresponding author email: agung.prabowo@unsoed.ac.id*)
}

\begin{abstract}
TN Roman 10pt)
The Rajaban tradition is a tradition of religious rituals as an expression of gratitude and moments to commemorate historical events, one of which is the change in the direction of Qibla from Baitul Maqdis to the Kaaba in Mecca. Based on these problems, in this article, it is shown by using the study of Graph Theory, namely the eccentric digraph to determine the center of the earth's region. Data processing is done by making the Kaaba and the seven continents on the earth's surface as a point on graph $\mathrm{G}$ and the side connecting the points is the distance (in $\mathrm{km}$ ) with physical boundaries between them being considered non-existent. The results of the discussion show that the Kaaba in Mecca is the center of the earth's area with ec(v1) $=12,039=\operatorname{rad}(\mathrm{G})$.
\end{abstract}

Keywords: Rajaban Tradition, Ethnomathematics, Eccentric Digraph, Center of the Earth, Kaaba.

\section{Introduction}

Mathematics and culture are two related sciences. According to (Knijnik, 1993), mathematics is knowledge from a culture that grows and develops to connect human needs. This can be interpreted that culture can produce mathematics as well as mathematics can produce culture where both epistemologically have the same foundation of thinking, namely a logical foundation.

Indonesia as a country consisting of islands has a variety of cultures on each island, especially the island of Java. One part of the island of Java is Banjarnegara Regency. The culture in Banjarnegara Regency is not much different from Javanese culture in general and generally every culture that is still preserved has a relationship with Islamic history, one of which is the Rajaban tradition.

The Rajaban tradition is a religious ritual tradition as an expression of gratitude. This tradition is held communally by Javanese Muslims every month of Rajab. Apart from being an expression of gratitude, this tradition is also a moment to commemorate historical events, such as the journey of the Prophet Muhammad. at night, 27 Rajab from the Grand Mosque in Mecca to the Aqsa Mosque in Baitul Maqdis, Palestine riding a burak; change of Qibla direction from Baitul Maqdis to Kaaba, Makkah; The Prophet's military victory over the Roman troops in the Battle of Tabuk and the liberation of Jerusalem from the clutches of the European Crusaders. Among these historical events, the only event that guides and is practiced by Muslims, especially Javanese Muslims is the change in the direction of Qibla in performing prayers (Fathonah, 2018; Farah, 2018)

Historically, the change in the direction of Qibla from Baitul Maqdis to the Ka'bah was an answer to the prayer of the Prophet Muhammad. due to the emergence of the assumption of the Jews in Medina against Islam that the religion brought by the Prophet Muhammad. This has followed the Qibla and their way of worship. This assumption gave birth to the ambition of the Jews to invite the Muslims to join them. Therefore, the Prophet Muhammad. ask Allah SWT. to 
send down revelations regarding the Qibla for the Muslims. As the word of Allah SWT (Mahmudah, 2020; Tanjung, 2017). as an answer to the prayer of the Prophet Muhammad. in Surah Al Baqarah verse 144, namely:

"Indeed We (often) see your face looking up at the sky, so We will surely turn you to the Qibla that you like. Turn your face towards the Grand Mosque. Every where you are, turn your face on him. And indeed those (Jews and Christians) who were given the Book (Torah and the Bible) do know that turning to the Grand Mosque is true from their Lord; and Allah is never heedless of what they do." (Jaelani, 2010; Faiz, 2020; Mutmainnah, 2017).

The change in the direction of the Qibla to the Kaaba in Mecca reminds the author of one of the words of Allah SWT. which mentions the Kaaba as the center, namely Surah Al Maidah verse 97 and reads:

"Allah has made the Kaaba, the holy house as the center (of worship and world affairs) for humans, and (as well as) the month of Haram, had-ya, qalaid. (Allah made that) so that you may know that Allah knows what is in the heavens and what is in the earth and that Allah is Knower of all things."

In one field of Mathematics study, Graph Theory, there is a special study, namely the Eccentric Digraph which explains its implementation in determining the center of a graph. The graph in question is a representation of objects in a single unit, for example a province area consisting of several districts (Wati, 2018).

Seeing the ethnomathematical analysis of the Rajaban tradition, the author is interested in applying mathematical science, namely Graph Theory to examine the Kaaba as the center of the region on earth using the study of Graph Theory, namely the implementation of the Eccentric Digraph. Generally, researchers and students discuss ethnomathematics more qualitatively. However, it is not uncommon for those who discuss it qualitativelyquantitatively, such as (Umbara, et al. 2021) discusses how to predict auspicious days for farming as a habit of the indigenous people of Cigugur, Kuningan Regency in an Ethnomathematical study with an (Ethnomodelling approach and (Laurens, 2016) describes ethnomathematical analysis and its application in improving the quality of learning. Prabowo (2020) produced a mathematical model to determine the execution time of the 1, 7, 40,100, 365, 720 and 1000 day death anniversary. In another research, (Prabowo 2000) also made a mathematical model related to the Aboge calendar used by Aboge Muslims, especially in the Cikakak area, Banyumas.

Based on the description on the background, the problem formulated is how to determine the center of the earth's area through the implementation of the Eccentric Digraph. The purpose of this study is to determine the center of the earth's area through the implementation of the Eccentric Digraph.

\section{Literature Review}

This chapter will discuss the basic concepts needed in the discussion section including the Rajaban Tradition and Ethnomathematics, Graph Theory which includes graphs, types of graphs and dual graphs, and Eccentric Digraphs which include eccentricity, eccentric point, radius, diameter, and point. center of a graph.

\subsection{Rajaban Tradition and Ethnomathematics}

The Rajaban tradition is a series of religious activities carried out in the month of Rajab. Rajaban itself is taken from the word 'Rajab' which is one of the months in the Hijri calendar. Javanese Muslims, especially Banjarnegara Regency, hold Rajaban as an expression of gratitude and moments to commemorate historical events, such as the journey of the Prophet Muhammad SAW. at night, 27 Rajab from the Grand Mosque in Mecca to the Aqsa Mosque in Baitul Maqdis, Palestine riding a burak; change of Qibla direction from Baitul Maqdis to Kaaba, Makkah; The Prophet's military victory over the Roman troops in the Battle of Tabuk and the liberation of Jerusalem from the clutches of the European Crusaders. Among these historical events, the only event that guides and is practiced by Muslims, especially Javanese Muslims is the change in the direction of Qibla in performing prayers (Farah, 2018; Zakaria, 2019).

Ethnomathematically, the Rajaban Tradition not only has a religious implementation but can also be implemented in mathematics learning, which is to attract students to analyze the time pattern of its implementation which is carried out in the month of Rajab, one of the months in the Hijri calendar. However, if you look further than the meaning of the implementation of Rajaban, namely as a warning of an important event in Islamic history, namely Isra 'Mi'raj Prophet Muhammad SAW. there are a lot of mathematical values that can be analyzed which aims to strengthen mathematical concepts and theories. For example, how is the pattern of the location points of the Isra 'Mi'raj of the Prophet Muhammad SAW., how to determine the center of the earth's territory graphically, and much more. In analyzing these matters to determine the implementation of mathematics learning, of course, it is also necessary to study other fields, namely the fields of history, geography to meta-physics.

This tradition if we look further, it has quite a lot of positive values, both in terms of psychic, social, to knowledge/reasoning power; analysis of students in implementing mathematical concepts that can refer to the time, how it is implemented to the values behind it. Through the implementation of mathematical concepts in the Rajaban tradition, it is hoped that students can more easily learn and understand new or previously studied mathematical topics. Because contextualized learning experiences will more influence the occurrence of the mathematics learning process, as we all know that the thinking processes taught and trained in mathematics learning such as thinking critically, creatively, systematically and realistically are very beneficial for human life. 


\subsection{Graph theory}

Graph theory is a branch of mathematics that studies the connectedness of certain objects. The relationship between the objects that occur is known as a graph. The following terms exist in graph theory.

\subsubsection{Graph}

The graph $\mathrm{G}$ is a structure $(\mathrm{V}, \mathrm{E})$ where $\mathrm{V}=\{\mathrm{v} 1, \mathrm{v} 2, \ldots\}$ a non-empty set whose elements are called vertices, while $\mathrm{E}=\{\mathrm{e} 1, \mathrm{e} 2, \ldots\}$ is the set of unordered pairs of elements. -element in $\mathrm{V}(\mathrm{G})$ and allow may be empty. The members of $\mathrm{E}(\mathrm{G})$ are called edges. Geometrically, a graph is described as a set of dots (points) in a two-dimensional plane connected by a set of lines (sides) (Rizki, 2012).

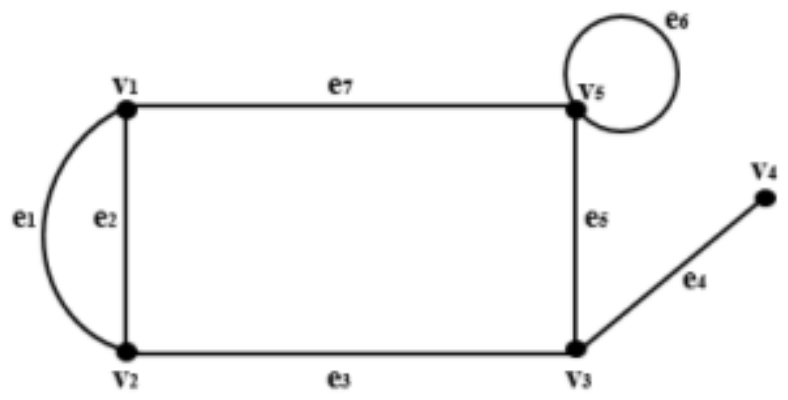

Figure 1. Graph $\mathrm{G}$ with a loop and double edges

In Figure 1, edges e 1 and e 2 are called double edges or parallel edges, while edges e6 are called loops because they connect the same starting and ending points. Side e 7 is adjacent to or incident to points $\mathrm{v} 1$ and v5, while point $\mathrm{v} 2$ is adjacent to point v3.

1. Degrees

The degree or degree of a point $\mathrm{v}$ is denoted by $\operatorname{deg}(\mathrm{v})$ is the number of sides that are adjacent to the point $\mathrm{v}$.

The example in Figure 2.1,

$\operatorname{deg}(v 1)=3$, that is $e 1, e 2$, and e7

$\operatorname{deg}(v 5)=3$, that is $\underline{e 5}, e 6$, and $\mathrm{e} 7$

$\operatorname{deg}(v 4)=1$, that is $e 4$ ( $v 4$ is called the earring point or pendant vertex)

2. Path (path)

A path is a path with different points on a graph. A path whose starting and ending points are the same is called a closed path or circuit.

The example in Figure 2.1,

Path $=\{v 1, e 1, v 2, e 3, v 3, e 4, v 4\}$

Circuit $=\{v 1, e 1, v 2, e 3, v 3, e 5, v 5, e 7, v 1\}$

3. Section Graph (subgraph)

A graph $\mathrm{H}$ is said to be a subgraph of $G(H \subseteq G)$ if only if $V(H) \subseteq V(G)$ and $E(H) \subseteq E(G)$.

On the other hand, if $(H \subseteq G)$ and $V(H)=V(G)$ then graph $\mathrm{H}$ is called the spanning subgraph of graph $\mathrm{G}$.

4. Complementary Graph

If $\mathrm{G}$ is a simple graph, then the complement of $\mathrm{G}$ is denoted by $\mathrm{G}$ is a graph whose vertex set is the same as the vertex set in $G$, and two vertices $u$ and $v$ in $G$ are neighbors if and only if the two vertices $u$ and $v$ are not neighbors in $G$.

\subsubsection{Types of graphs}

Types of graphs are distinguished based on their properties and characteristics. Based on the presence or absence of loops or double edges in a graph, the graph is classified into two, namely:

1. Simple graph (simple graph)

A simple graph is a graph that does not contain loops or double edges.

2. Unsimple Graph

A non-simple graph is a graph that contains loops or double edges.

Based on the orientation of the edges, graphs are generally classified into two, namely:

1. Undirected Graph

An undirected graph is a graph in which each edge does not contain a direction orientation.

2. Direct Graph

A directed graph is a graph in which each edge contains a direction orientation either out or into a vertex.

The following shows an example in Figure 2. 


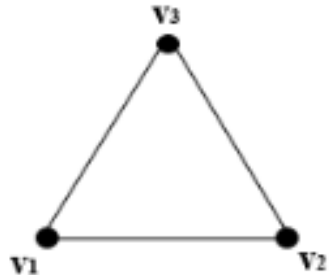

(a)

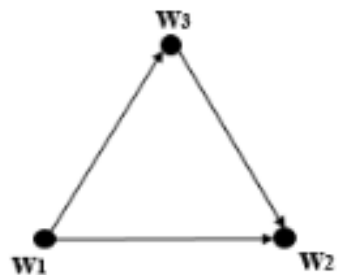

(b)

Figure 2. (a) Undirected graph and (b) Directed graph

Based on the weights on the side of the graph, graphs are generally classified into two, namely:

1. Unweighted Graph

An unweighted graph is a graph in which each edge is not assigned a value (weight).

2. Weighted Graph

A weighted graph is a graph in which each edge is assigned a value (weight). The weights on each side can represent the distance between two cities, the cost of traveling between two cities, the travel time or installation costs from one communication node to another in a computer network, or the cost of building a highway between two cities. The following shows an example in Figure 3.

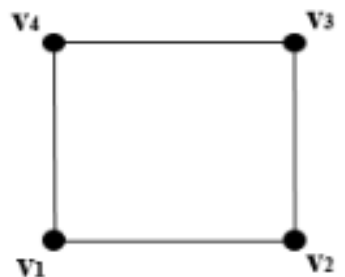

(1)

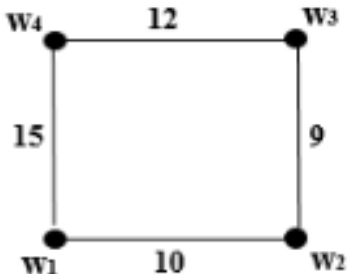

(2)

Figure 3. Unweighted graph and (2) Weighted graph

\subsection{3. dual graph}

A graph that can be displayed geometrically with edges that do not intersect is called a plane graph or planar graph. For example, a plane graph $\mathrm{G}$ The following shows an example in Figure 4.

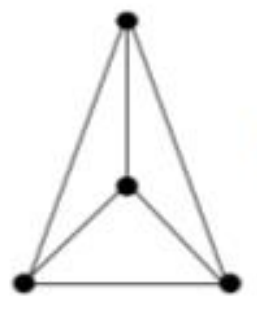

(a)

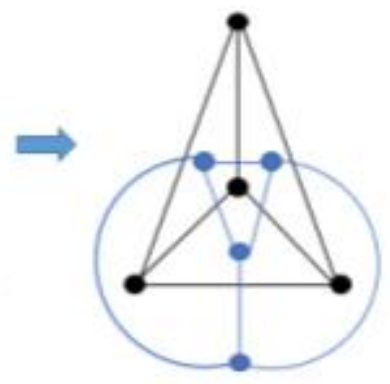

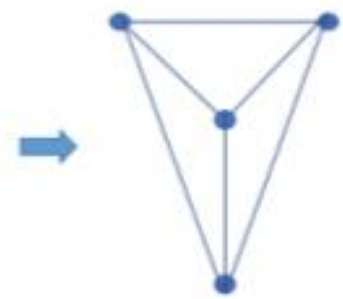

(b)

Figure 4. (a) Plane graph G and (b) Dual graph of plane graph G

\subsection{Eccentric Digraph}

An eccentric digraph on a graph $G$ or $E D(G)$ is a directed graph $G$ (can be alternating) which has the same set of vertices as $G$ or $V(E D(G))=V(G)$ and the set of directed edges $A(E D(G))$ whose elements are edges in the direction of $\mathrm{uv}$ joining the points $\mathrm{u}$ and $\mathrm{v}$ if $\mathrm{v}$ is the eccentric point of $\mathrm{u}$, or it can be written, $A(E D(G))=\{u v \mid v$ is the eccentric of the point $u$.

In determining an eccentric digraph, it is very important to know the eccentricity points of every vertex on a graph.

A. Eccentricity 
The eccentricity of point $v$ is denoted by $e c(v)$ is the farthest distance (maximum shortest path) from vertex $v$ to any vertex in graph $G$ or it can be written, $e c(v)=\max \{d(v, u) \mid u$ are the points in the graph $G\}$. The following shows an example in Figure 5.

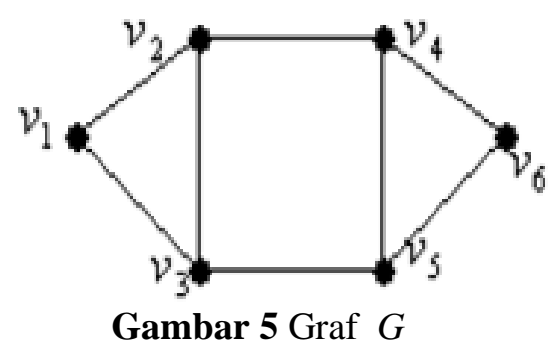

Figure 5. can show the eccentricities of several points in graph G, namely:

$$
\begin{aligned}
e c(v 1) & =\max \{d(v 1, v 2), d(v 1, v 3), d(v 1, v 4), d(v 1, v 5), d(v 1, v 6)\} \\
& =\max \{1,1,2,2,3\}=3 \\
e c(v 2) & =\max \{d(v 2, v 1), d(v 2, v 3), d(v 2, v 4), d(v 2, v 5), d(v 2, v 6)\} \\
& =\max \{1,1,1,2,2\}=2 \\
e c(v 3) & =\max \{d(v 3, v 1), d(v 3, v 2), d(v 3, v 4), d(v 3, v 5), d(v 3, v 6)\} \\
& =\max \{1,1,2,1,2\}=2
\end{aligned}
$$

B. Eccentric Point

The point $\mathrm{v}$ is called the eccentricity of $\mathrm{u}$, if the distance from $\mathrm{v}$ to $\mathrm{u}$ is equal to the eccentricity of $\mathrm{u}$ or $d(u, v)$ $=e c(u)$. By using Figure 2.5 it can be shown the eccentric points of several points in graph G, namely:

$e c(v 1)=3$, meaning that the eccentric point of $v 1$ is $v 6$

$e c(v 2)=2$, meaning that the eccentric points of $v 2$ are v5 and $v 6$

$e c(v 3)=2$, meaning that the eccentric points of $v 3$ are $v 4$ and $v 6$

C. Radius

The radius of the graph $G$ is the minimum eccentricity at any point in $G$, or it can be written as $\operatorname{Rad}(G)=$ $\min \{\mathrm{ec}(\mathrm{v}) \mid \mathrm{v} E \mathrm{~V}(\mathrm{G})\}$. By using Figure 2.5 it can be shown the radius of graph $\mathrm{G}$, namely:

$\operatorname{Rad}(G)=\min \{e c(v 1), e c(v 2), e c(v 3), e c(v 4), e c(v 5), e c(v 6)\}$

$$
=\min \{3,2,2,2,2,3\}=2
$$

D. Diameter of graph $\mathrm{G}$ or $\operatorname{rest}(\mathrm{G})$

The diameter of the graph $\mathrm{G}$ is the maximum eccentricity at any point in $\mathrm{G}$, or it can be written with rest $(\mathrm{G})$ $=\max \{e c(v) \mid v E V(G)\}$. By using Figure 2.5 it can be shown the diameter of the graph G, namely:

$\operatorname{silent}(G)=\max \{e c(v 1), e c(v 2), e c(v 3), e c(v 4), e c(v 5), e c(v 6)\}$

E. Center point of graph $\mathrm{G}$

$$
=\min \{3,2,2,2,2,3\}=3
$$

The vertex $v$ in graph $G$ is called the center of $G$ if the eccentricity of the vertex $v$ is equal to the radius $G$, or it can be written as ec(v) $=\operatorname{Rad}(\mathrm{G})$. By using Figure 2.5 it can be shown the center point of graph $\mathrm{G}$, namely:

$\operatorname{Rad}(G)=2$,

This means that ec(v2), ec(v3), ec(v4), and ec(v5) are the center points of graph $G$.

\section{Methodology}

In the research methods section, a series of workflows from research preparation, research implementation and research report preparation are discussed. The following workflow in this study is shown in Figure 6. 


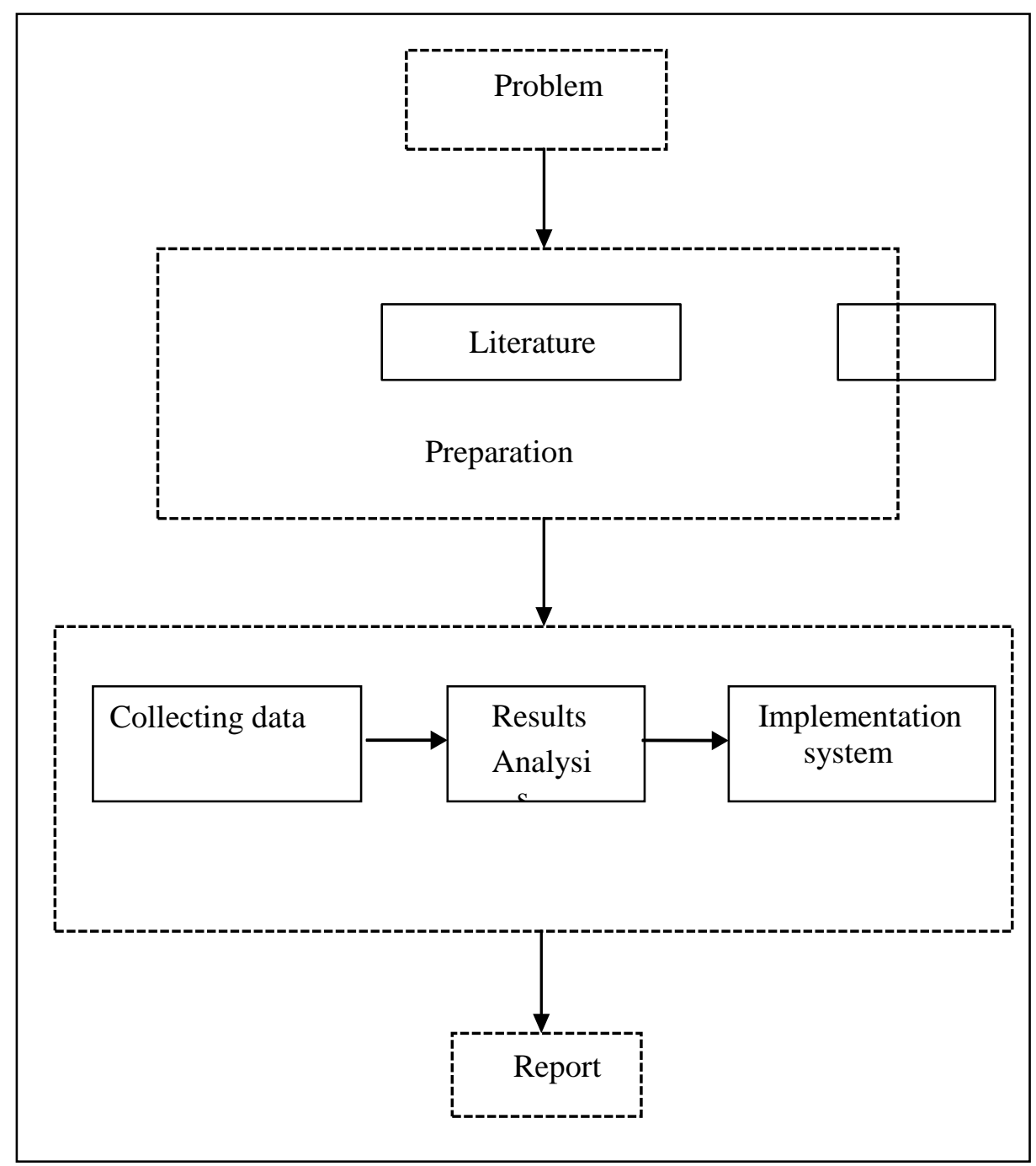

Figure 6. Research Workflow

\subsection{Research Preparation}

\subsubsection{Research Library Collection}

The collection of research literature is taken from various sources such as books, articles, journals and theses related to the basic concepts of graph theory and its application to determining the center point of a graph.

\subsubsection{Determination of Research Objects}

The object of research in this study is to determine the center of the region on earth by representing the Kaaba and the seven continents as points of a graph.

\subsection{Research Implementation}

\subsubsection{Data Collection}

The data used in this study is secondary data, namely data obtained from the results of distance measurements using the Google Map application. The points on graph G represent the Kaaba and the seven continents on the earth's surface. Physical boundaries between the Kaaba and continents are considered non-existent so that the weight of the distance used is the closest distance between the Kaaba and the continent by using distance measurements on the Google Map application. 


\subsubsection{Data Management}

Data processing uses an eccentric digraph as a solution for determining the center of the earth's area through the implementation of an eccentric digraph.

\section{Results and Discussion}

The data used in this study is secondary data, namely data obtained from the results of distance measurements using the Google Map application. With manual work, a representation is obtained in the form of a graph or hereinafter referred to as graph $\mathrm{G}$ which is shown in Figure 4.1.

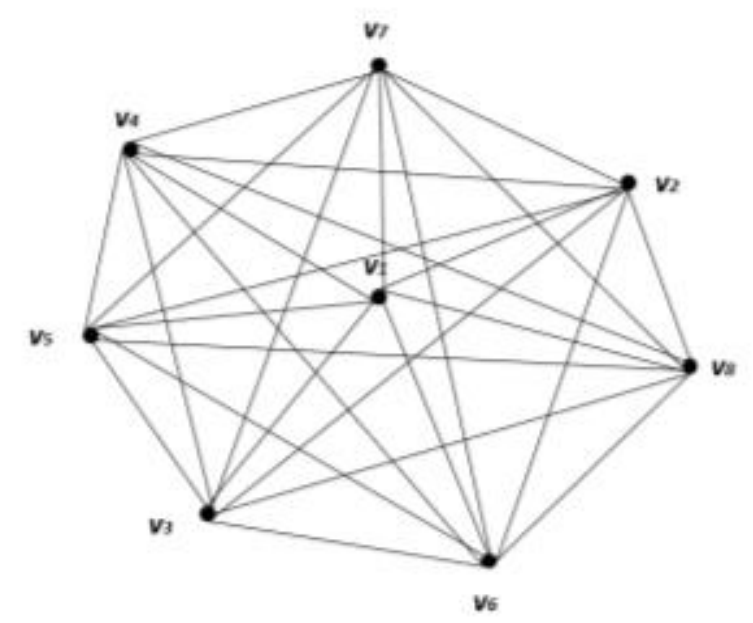

Description:

Figure 7. Graph $\mathrm{G}$ representing the earth's surface area

V1 :Asian continent

V2 :The African continent

V3 :North America

V4 :South America Continent

V5 :Antarctica

V6 :Continent of Europe

V7 :Australian Continent

\subsection{Determining Distance Weight}

In determining the weight of the distance between points or locations, the "Measure Distance" feature in the Google Map application is used with the following steps:

1. Right-click the mouse on the starting point $>$ select the "Measure Distance" feature. 


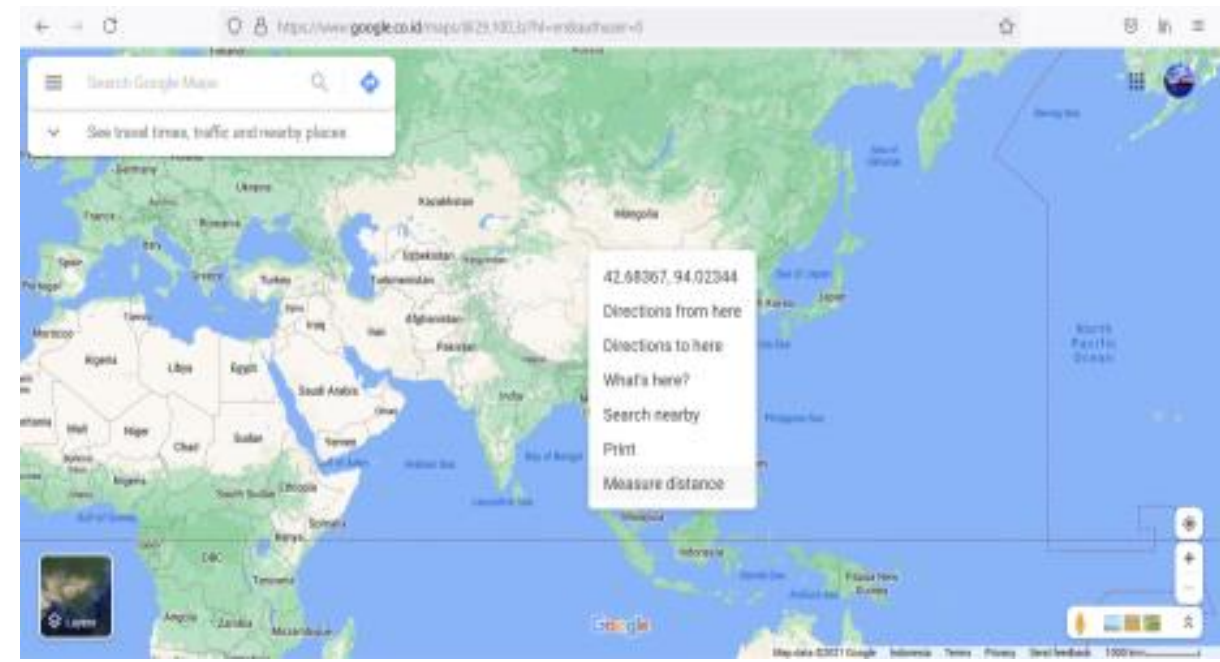

2. Left mouse click on the destination or end point.

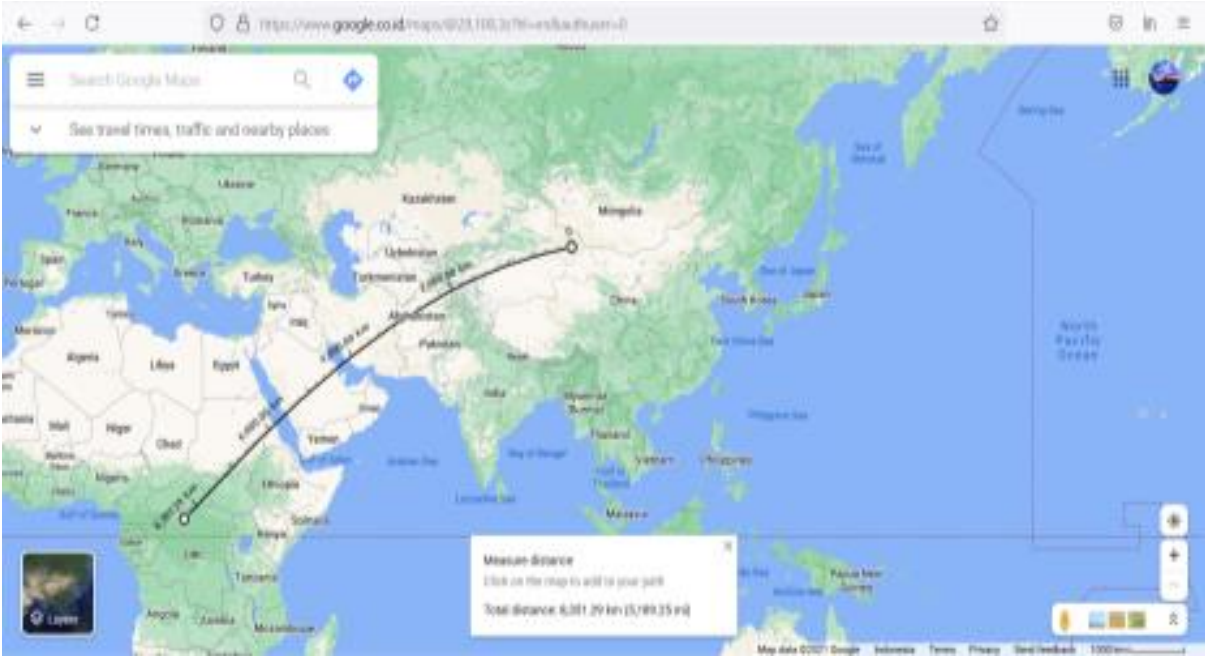

Distance results will be displayed in meters in the description below. With the same steps applied to the connectivity of all location points, Table 1 .

Table 1. Order of weighted distances between Kaaba and continents

\begin{tabular}{|l|r|r|r|r|r|r|r|r|}
\hline Wilayah & \multicolumn{1}{|l|}{ Ka'bah } & \multicolumn{1}{|l|}{ Asia } & Afrika & $\begin{array}{l}\text { Amerika } \\
\text { Utara }\end{array}$ & $\begin{array}{l}\text { Amerika } \\
\text { Selatan }\end{array}$ & Antartika & Eropa & Australia \\
\hline Ka'bah & 0 & $6.006,50$ & $3.326,53$ & $10.845,54$ & $10.917,88$ & $12.003,39$ & $4.246,49$ & $11.294,98$ \\
\hline Asia & $6.006,50$ & 0 & $8.403,64$ & $9.833,74$ & $16.258,51$ & $13.238,19$ & $6.707,52$ & $7.380,21$ \\
\hline Afrika & $3.326,53$ & $8.403,64$ & 0 & $13.683,45$ & $9.771,87$ & $8.792,20$ & $7.193,85$ & $10.582,65$ \\
\hline $\begin{array}{l}\text { Amerika } \\
\text { Utara }\end{array}$ & $10.845,54$ & $9.833,74$ & $13.683,45$ & 0 & $8.467,86$ & $16.635,55$ & $6.690,88$ & $14.171,87$ \\
\hline $\begin{array}{l}\text { Amerika } \\
\text { Selatan }\end{array}$ & $10.917,88$ & $16.258,51$ & $9.771,87$ & $8.467,86$ & 0 & $9.481,33$ & $9.562,82$ & $16.209,50$ \\
\hline Antartika & $12.003,39$ & $13.238,19$ & $8.792,20$ & $16.635,55$ & $9.481,33$ & 0 & $15.906,56$ & $6.893,00$ \\
\hline Eropa & $4.246,49$ & $6.707,52$ & $7.193,85$ & $6.690,88$ & $9.562,82$ & $15.906,56$ & 0 & $14.010,50$ \\
\hline Australia & $11.294,98$ & $7.380,21$ & $10.582,65$ & $14.171,87$ & $16.209,50$ & $6.893,00$ & $14.010,50$ & \\
\hline
\end{tabular}

After the distance weight of each point connection is known, then the eccentric digraph of graph $G$ will be determined based on Table 1 . 


\subsection{Eccentric Digraph}

We will determine the eccentricity of each vertex or region from Table 1 to further determine the eccentric digraph of graph G. Note that the point eccentricity or $\operatorname{ec}(\mathrm{v})=\max \{\mathrm{d}(\mathrm{v}, \mathrm{u}) \mid \mathrm{u}$ are the points in the graph $\mathrm{G}\}$. The vertex eccentricity of each vertex in graph $\mathrm{G}$ is shown in Table 2 .

Table 2 The vertex eccentricity of each vertex in the graph G

\begin{tabular}{|c|c|c|c|c|c|c|c|c|c|}
\hline Wilayah & Ka'bah & Asia & Afrika & $\begin{array}{l}\text { Amerika } \\
\text { Utara }\end{array}$ & $\begin{array}{l}\text { Amerika } \\
\text { Selatan }\end{array}$ & Antartika & Eropa & Australia & $e(v)$ \\
\hline Ka'bah & 0 & $6.006,50$ & $3.326,53$ & $0.845,54$ & $0.917,88$ & $12.003,39$ & $4.246,49$ & $1.294,98$ & $12.003,39$ \\
\hline Asia & $.006,50$ & 0 & $8.403,64$ & $9.833,74$ & $16.258,51$ & $13.238,19$ & $6.707,52$ & $7.380,21$ & $16.258,51$ \\
\hline Afrika & $3.326,53$ & $8.403,64$ & 0 & $13.683,45$ & $9.771,87$ & $8.792,20$ & $7.193,85$ & $10.582,65$ & $13.683,45$ \\
\hline $\begin{array}{l}\text { Amerika } \\
\text { Utara }\end{array}$ & $10.845,54$ & $9.833,74$ & $13.683,45$ & 0 & $8.467,86$ & $16.635,55$ & $6.690,88$ & $14.171,87$ & $16.635,55$ \\
\hline $\begin{array}{l}\text { Amerika } \\
\text { Selatan }\end{array}$ & $10.917,88$ & $16.258,51$ & $9.771,87$ & $8.467,86$ & 0 & $9.481,33$ & $9.562,82$ & $16.209,50$ & $16.258,51$ \\
\hline Antartika & $12.003,39$ & $13.238,19$ & $8.792,20$ & $16.635,55$ & $9.481,33$ & 0 & $15.906,56$ & $6.893,00$ & $16.635,55$ \\
\hline Eropa & 46,49 & $6.707,52$ & $7.193,85$ & $6.690,88$ & $9.562,82$ & $15.906,56$ & 0 & $14.010,50$ & $15.906,56$ \\
\hline Australia & $11.294,98$ & $7.380,21$ & $10.582,65$ & $14.171,87$ & $16.209,50$ & $6.893,00$ & $14.010,50$ & 0 & $16.209,50$ \\
\hline
\end{tabular}

Description:

- The eccentric point of the Kaaba is Antarctica

- The eccentric point of Asia is South America

- The eccentric point of Africa is North America

- The eccentric point of North America is Antarctica

- The eccentric point of South America is Asia

- The eccentric point of Antarctica is North America

- The eccentric point of Europe is Antarctica

- The eccentric point of Australia is South America

By considering the concept of the center point of graph $G$, namely ec(v) $=\operatorname{Rad}(G)$ where $\operatorname{Rad}(G)=\min \{e c(v) \mid v E$ $V(G)$, meaning that the radius of the graph $G$ is $12,003.39 \mathrm{~km}$. Therefore, it can be seen that the center point of the graph $G$ is the Kaaba.

\section{Conclusions And Suggestions}

\subsection{Conclusion}

Based on the results and discussion regarding the application of the Eccentric Digraph on the distance between the Kaaba and the continents to determine the center of the region from the earth, it is obtained that the eccentricities of the Kaaba, the Asian continent, the African continent, the North American continent, the South American continent, the Antarctic continent, the European continent, and the Australian continent are: 12,003,39; 16,258.51; 13,683.45; $16,635.55 ; 16,258.51 ; 16,635.55 ; 15,906.56$; and $16,209.50$. Also obtained, the radius of the region which is the smallest eccentricity of the region is 12,003.39. Based on the theory on the Eccentric Digraph, the center point of an area is a point where the eccentricity is the same as the radius of the area, so the center point of the earth's area is the Kaaba with ec(v1) $=12.003 .39=\operatorname{rad}(\mathrm{G})$.

\subsection{Suggestion}

1. Further research is recommended to conduct field analysis so that the data in the form of distance weights obtained are more concrete so that more optimal results are obtained.

2. Further research is recommended in solving problems using TSP modeling to create algorithms using computer programs so that calculations are more efficient and more accurate results are obtained. 


\section{References}

Faiz, A. K. (2020). Moderasi Fiqh Penentuan Arah Kiblat: Akurasi Yang Fleksibel. JIL: Journal of Islamic Law, 1(1), 83-99.

Farah, N. (2018). Nilai-Nilai Filosofis Dalam Tradisi Rajaban Di Kesultanan Kanoman Cirebon. IBDA: Jurnal Kajian Islam Dan Budaya, 16(2), 303-327.

Farah, N. (2018). Nilai-Nilai Filosofis Dalam Tradisi Rajaban Di Kesultanan Kanoman Cirebon. IBDA: Jurnal Kajian Islam Dan Budaya, 16(2), 303-327.

Fathonah, S. (2018). Kompleksitas Simbol Dan Representasi Makna Dalam Tradisi Rajaban Masyarakat Kebumen. Al-A'raf: Jurnal Pemikiran Islam dan Filsafat, 15(2), 273-294.

Jaelani, A. (2010). Akurasi Arah Kiblat Masjid Agung Sunan Ampel Surabaya Jawa Timur (Doctoral dissertation, IAIN Walisongo).

Knijnik, G. (1993). An ethnomathematical approach in mathematical education: A matter of political power. For the learning of mathematics, 13(2), 23-25.

Laurens, T. (2016). Analisis Etnomatematika dan Penerapannya dalam Meningkatkan Kualitas Pembelajaran. Jurnal Pendidikan Matematika STKIP PGRI Sumbar, 3(1), 86-96.

Mahmudah, K. N. L. (2020). Paradigma Pendidikan Islam dalam Perspektif Tafsir Surat Al-Baqarah Ayat 129 dan 151. TARBAWI: Jurnal Pendidikan Agama Islam, 5(02), 144-160.

Mutmainnah, M. (2017). Kiblat Dan Kakbah Dalam Sejarah Perkembangan Fikih. Ulumuddin: Jurnal Ilmu-ilmu Keislaman, 7(1), $1-16$.

Prabowo, A. Sukono, Mamat, M., Wahyudin, and Budiono, R. 2020. Ethnomodelling: Aboge Cikakak Calendar Convertion into Gregorian Calendar using Brute Force Algorithm. International Journal of Advanced Science and Technology, 29(7): 1633 1646.

Prabowo, A. Sukono, Mamat, M., Wahyudin, and Budiono, R. 2020. Mathematical Model for Commemoration of Death in Javanese Tradition. International Journal of Advanced Science and Technology, 29(5): 162 - 168.

Tanjung, D. (2017). Urgensi Kalibrasi Arah Kiblat dalam Penyempurnaan Ibadah Salat. Al-Manahij: Jurnal Kajian Hukum Islam, 11(1), 113-132.

Umbara, U., Susilana, R., \& Puadi, E. F. W. (2021). Algebra Dominoes Game: Re-Designing Mathematics Learning During the Covid-19 Pandemic. International Journal of Instruction, 14(4).

Wati, S. (2018). Digraf Eksentrik dari Graf Tangga dan Graf Bipartisi Lengkap. interaksi: Jurnal Kependidikan, 13(1).

Zakaria, A. (2019). Isra Mi'raj Sebagai Perjalanan Religi: Studi Analisis Peristiwa Isra Mi'raj Nabi Muhammad Menurut Al Qur'an Dan Hadits. Al-Tadabbur: Jurnal Ilmu Al-Qur'an dan Tafsir, 4(01), 99-112. 